\title{
The Impact of the 4th Industrial Revolution Outcomes on the Economic Role of the State Egypt as a Case Study (2013-2021)
}

Ghada Ali Moussa, Ph.D. Iman Al Shaer, Ph.D.

Lecturer at the Faculty of Lecturer at the Faculty of Economics and Politics, New Economics and Political Giza University Sciences, Cairo University 


\section{Abstract}

This paper explains the changes that occurred in the economic role of the state due to the $4^{\text {th }}$ industrial revolution (4.0); Egypt as the case study. The paper examines two hypotheses. The first hypothesis assumes that while the state in Egypt is struggling with its economic role, the 4.0 poses challenges to that role. The second hypothesis assumes that formal institutions did not benefit from the 4.0 outcomes, which did not result in transforming its role and policies and in positively achieving economic growth. The paper adopts the new-institutionalism approach, that perceives a state that maximizes preferences of the individuals and various organizations. Part I provides an analysis of the theoretical claims of the economic role of the state. Part II discusses the impact of the 4.0 on re-shifting the focus from the state to the individual. Part III examines the process of matching state capabilities with its digital transformation policies to foster economic growth. The research results found that state institutions took "slow steps" to benefit from the opportunities of the revolution 4.0., which resulted in a limited impact on the economic growth. State institutions provided a small margin of freedom to allow individuals to perform economic activities, that could lead Egypt to achieve a knowledge-based economy.

Keywords: State, Economic Role, New Institutionalism, Technology, $4^{\text {th }}$ Industrial Revolution.

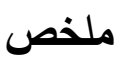

$$
\begin{aligned}
& \text { توضح هذه الورقة البحثية التغيرات التي طرأت على الدور الاقتصادي للدولة بسبب الثورة } \\
& \text { الصناعية الرابعة (4.0). مصر كدراسة حالة. وتسعى الورقة لاختبار فرضين بحثيين مفادهما أن } \\
& \text { الدولة في مصر تصارع من أجل تحديد طبيعة دورها الاقتصادي، وأن مخرجات } 4.0 \text { تمثل تحديا } \\
& \text { لهذا الدور ـ أما الفرضية الثانية فهي عدم استفادة مؤسسات الدولة من مخرجات 4.0, حيث لم يسفر } \\
& \text { ذلك عن تغير في دورها الاقتصادي وسياساتها وفي قدرتها على تحقيق النمو الاقتصادي. وتتبنى }
\end{aligned}
$$


الورقة الاقتراب المؤسسي الجديد، الذي يشير إلى الدولة التي تعظم من تفضيلات الأفراد والمنظمات

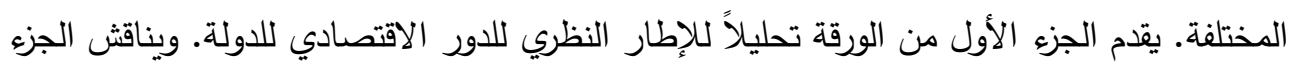
الثاني تأثير 4.0 على عودة تحويل التركيز من الدولة إلى الفرد. ويبحث الجزء الثالث في مواءمة لهاء قدرات الدولة مع سياسات التحول الرقمي لتعزيز النمو الاقتصادي. وأثارت نتائج البحث إلى أنى أن لترديل

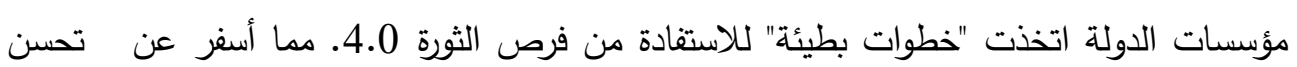
محدود في معدلات النمو الاقتصادي. كما أتاحت مؤسسات الدولة هامش محدود من الحرية للسماح للأفراد بأداء الأنشطة الاقتصادية، التي يمكن أن تتقل مصر إلى اقتصاد المعرفة.

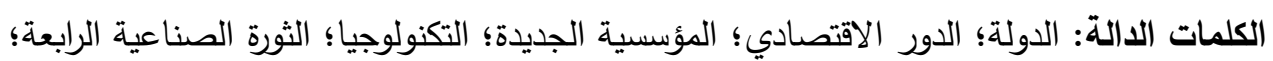

\section{Introduction}

Determining the economic role of the state and society has long been a central concern of economic and political science theories. Although the state still occupies a relative central role in the provision of basic services such as education, health and infrastructure, the state's choices about providing, financing, and regulating these services is now built on the relative power of state institutions, markets, private sector, and civil society.

Before the advent of economic liberalism, the economic role of the state was taken for granted, because the extent of state intervention in the economic affairs was considered a political subject, rather than an economic decision. (Aubrey, Henry G. 1951, p.267) However, developments occurred in the state intervention concepts in the market economy, which evolved around the available options for the state to pursue a specified economic role, in addition to questioning the effectiveness of its polices, and whether non-state actors and private institutions are likely to deliver better outcomes than the state. (Helm, Dieter, 1986, p.2). In that relation four ideal-type conceptions of the role of the state could be identified: the first conception is the liberal one that perceives the state as a provider of public goods that markets will not produce (defense, roads, etc.). The second conception perceives the state more than 
the political expression of the dominant class in society. The third conception of the role of the state could be conceptualized as a combination of individual careers and organizational interests that are primarily self- serving. The fourth conception is a nationalist one where state institutions mobilize societal

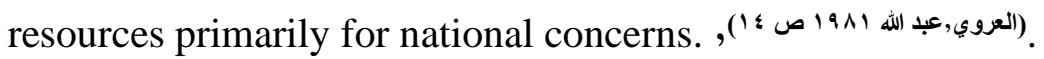

Studying the impact of the $4^{\text {th }}$ industrial revolution $(4.0)^{(1)}$, which is also called the digital revolution on the economic role of the state implies examining the concept of the state as a combination of individual careers and state institutions 'interests and implies also examining the impact of industrialization on state- society relationship to accelerate economic growth. During the twentieth century economic growth was accelerated due to the machine -industry, which resulted in the rise in domestic production, and an increasing demand for primary commodities, that were provided by underdeveloped countries. A series of innovations in machines, and the increase in capital formation by merging state and private capital resulted in vast trade and profits. Western industries could keep the capital but could not keep the technology for itself for a long time. Governments in England and in other parts of the Western world assisted in the spread of the first industrial revolution outcome. This happened without a considerable role of the state. (Aubrey, Henry G.,1951, pp.269- 270)

The role of the state was later emphasized by implementing the ideas of the welfare state in both developed and underdeveloped countries. (Goulborne, Harry, 1979, p.12). The fundamental theories of welfare economies were criticized in the $19^{\text {th }}$ and $20^{\text {th }}$ centuries and paved the way for the classical articulation of Adam Smith's invisible hand conjecture and set the role of the state in the

(1) The $4^{\text {th }}$ industrial revolution is defined by the World Bank as turning ideas into products, such as innovations, material sciences, artificial intelligence aiming at transforming the global economy. (World Bank, Country Inequality Report, 2016). 
framework of the market. (Stiglitz, Joseph E., 1991, p.19). ${ }^{(2)}$ The role of the state in the provision of goods was re- shaped by the recent developments in the digital products of 4.0 .

Hence, the objective of the research paper is to analyze the impact of the 4.0 on the economic role of the state in Egypt during the period 20132020. This will be through studying the economic role of the state, the role of the institutions and individuals in different theoretical settings, and through examining how these roles were reflected in the various implemented digital transformation policies.

The importance of the paper lies in its theoretical foundation to examine the impact of different schools of liberal thought on the economic role of the state and non-state actors manifested in the provision of digital products. The paper presents an in-depth analysis of the recent digital policy developments and economic growth in Egypt. It is worth clarifying that the aim of this paper is not to make ICT and digitalization appear as public goods, but to analyze how the state institutions perceive it to improve policy guidance and participation with non - state actors.

\section{Research Problem and Research Questions}

Recent developments in digitalization manifested by the fourth industrial revolution (4.0) outcomes have challenged the economic role of the state in Egypt. Despite the various policies and digital transformation strategies, it did not have an impact on the economic growth.

(2) Following the path of the industrial revolutions, the first industrial revolution was about steam and water, the second was about electricity and mass production, the third industrial revolution harassed electronics and information technology to automate production. The $4^{\text {th }}$ industrial revolution is about turning ideas into products such as innovations, material sciences, artificial intelligence aiming at transforming the global economy., Country Inequality Report, 2016). 
The research paper addresses three questions. The first question examines how the 4.0 outcome affected the economic role of the state. The second question is about to what extent did Egypt benefit from the products of 4.0 in providing public goods and accelerating economic growth. The third question is concerned with what types of consensuses have developed between the state and society that allow for individuals innovation to be included in the knowledge economy in Egypt.

The research paper aims at examining two hypotheses. The first hypothesis assumes that while the state in Egypt is struggling with its economic role, the 4.0 poses challenges to that role. The second hypothesis assumes that formal institutions did not benefit from the 4.0 outcomes, which did not result in transforming its role and policies and in positively influencing the economic growth in Egypt.

\section{Theoretical approach}

In answering the previous research questions, the paper adopts the new-institutionalism approach to constitute a theoretical political foundation for the economic role of the state.

Institutions are defined as "the ruler of the game in society", which embody and guide patterns of behavior. They consist of regularized interactions. And differences in institutions are the primary reason for differences in economic outcomes (North, Douglas C., 1990, p.18). Institutions matter in shaping the economic performance, which is a central tenet of both old (classical) and new institutionalism. (Weingast, Barry R.,1995, p.4).

Klein distinguished "Old and New Institutionalism". In "Old Institutionalism "the economy is a system that embraces a body of knowledge, and of skills and a stock of physical equipment, it also embraces a complex network of personal relations reinforced by custom, rituals, sentiment, and dogma. (Klein, Philip, 1977, p.787). In New institutionalism, the state 
is an autonomous entity, where diverse interest group coalitions are formed and negotiated. It maximizes preferences of organizations as well as itself being shaped by their behavior. New Institutionalism views the individual as a rational chooser, while old intuitionalism views the individual as a cultural product. (Rutherford, Malcolm ,1995, p.443). New institutionalism includes considerations of ideologies, altruism, and self-imposed standards of construction models of individual behavior (Weingast, Barry R., 1995, p.6). Both, old and new institutionalism recognize that institutions change over time and respond to economic developments.

New-Institutionalism approach assumes that the suitable political system for achieving economic development depends on the role of the institutions. In analyzing the role of the institutions in generating economic growth, the rigidity of the institutional framework and its capacity to adapt and absorb economic changes, particularly disruptive forces of industrialization are crucial. (Eckstein, Alexander,1958, p.81). A major contribution of new institutionalism is enhancing the economic role of the state through co-ordination and reconciliation of interests, strengthening decentralization processes and competitiveness, and ensuring equal opportunity in an open market environment (Hira, Anil, Hira, Ron, 2000, pp.268-269).

New institutionalists explain institutional change in two ways: first, institutions change in reaction to new factors, reflecting the change in relative prices and tastes. Second, entrepreneurs, whether individuals or organizations, exploit openings within the institutions, such as innovations. (Weingast, Barry R.,1995, p.10). Institutional change may also come from groups outside the institution such as interest groups, who could make changes in the identity, interest, or power of the institution over time (Hira, Anil,2000, p.277). Institutional change focus on capable institutions that could lay foundations, such as laws, property rights regulations, policy stability concerning taxes and 
financing, in addition to investment in infrastructure. Capable institutions are less centralized institutions, because technology and innovations cannot be centralized. Innovations survive in more competitive environment, and could relocate itself easily and quickly, because it is not confined and restricted by borders (Maki, Uskali,1993, p. 39 also Hayek, F.A., 1948, p.4).

Therefore, decentralized institutional structures impact innovation activities that are related to technological change, because it provides the fundamental driving force in increasing income. (Hira, Anil, 2000, pp.273, 277). The institutional structure affects the incentives to innovate, which is critical to economic growth. And reflects the amount of attention paid by the state institutions to interact and coordinate with individuals. (Weingast, Barry R.,1995, p.15 also Veblen, Thorstein,1964, p.448).

\section{Research Design}

The research paper applies a theoretical and a practical approach to respond to the research questions and test the two hypotheses. It is divided into three parts:

Part one provides a theoretical analysis of the economic role of the state and the consensuses it pursues between institutions and individuals. This is done by examining the debate on the role of the state in providing public goods including digital products.

Part two analyses the impact of the 4.0 products on re-shifting the focus from the role of the state to the role of the individual. This part discusses the theoretical claims related to the role of individual in the economic order shaped by the outcomes of the 4.0, and how state actors perceived this role. It also examines the political economy of the role of the individual during the 4.0 .

Part three examines the digital transformation policies adopted by the state in Egypt tand its capabilities to realize it. It starts with a brief historical 
discussion on the development of the economic role of the state in Egypt and its nature. Then it discusses the role of the ICT sector in the Egyptian economy. This is done through studying the various ICT and digital transformation policies and strategies issued by official institutions in Egypt, and the roles assigned to non -state actors in it. This part refers to related indices to examine to what extent did the 4.0 products accelerate and improve economic growth in Egypt. And the consensus types between the state and individuals' innovations to embrace the opportunities of the knowledge economy.

The conclusion tests the two hypothesis and suggests recommendations for future research on the importance of continuing measuring the impact of 4.0 on the economic growth in Egypt. It suggests policy recommendations to maximize the benefits from the digital transformation in providing sustainable goods and services and achieving the 2030 strategic goals.

\section{Literature Review}

The literature on the impact of digitalization on the economy and society varied. State facilitated innovation and the creation of a digital and knowledge economy. It is considered one of its important roles. (Hanna, Nagy, 2018) The development of ICT changed the socio-economic life of the individual. It opened opportunities, but threatened his privacy (Khan, Muhammad Zubair et al, 2013). Studies also examined the impact of digitalization on the economy through highlighting its benefit in cutting costs in production, communication, and organization. (Khan, Saima, Shazia Khan et al, 2015). Studies focused as well on the importance of the investment in ICT to enhance economic growth. Other focused on analyzing economic growth theories (Naasab, Ebrahim, Majid Aghael, 2009) and measuring the contribution of ICT in the economic growth (Kheng Soon, Kelly, 2010) (OECD,2004, https://www.oecd- 


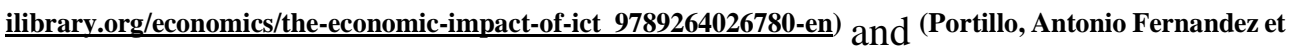
al, 2020)

Further studies examined the impact of ICT on enhancing productivity especially in firms through analyzing the effect of shifting from heavy machinery to information processing equipment in increasing productivity (Murakami, Takeshi, 1997) Another aspect of the impact of ICT on economic growth is also manifested in enhancing businesses and influencing financial results (Bilan, Yuriy et al, 2019)

The positive influence of ICT market on economic growth is verified by numerous research papers that focused on the ICT market from a supply and demand perspective. Samia Satti in its study on the impact of ICT on economic development in Egypt and the Gulf countries proved the existence of a correlation between ICT and economic development and that spending on ICT positively affects economic growth and human capital education (Satti, Samia, M.Nour, 1998). Similar studies examine the causal relationship between ICT and economic growth by comparing this relationship in country specific studies such as in high and middle -income countries. (Kurniawati, Meta Ayu, 2021).

When considering the role of state institutions in encouraging the inclusion of ICT and digital technologies in its policies, it is important that these policies overcome the digital divide and diffuse innovation and ICT resources by individuals, organizations, corporations, associations, schools (Kamel, Sherif, 2007) and (Ministry of Communications and Information Technology-MCIT Egypt's ICT Golden Book ,2007)

The impact of ICT on the economic role of the state were studied in the previous literature mainly through its direct impact on the economic performance with little focus on the different roles that different institutions and non- state actors pursue to achieve digital transformation. 


\section{Part I. Analysis of the theoretical claims of the economic role of the state and the consensus building between institutions and individuals}

Different stages of liberalism could be identified when reviewing the theoretical claims that explained the evolution of the economic role of the state in the different school of thoughts.

Reisman affirms that Adam Smith was not an economic anarchist. The governmental activities formed an inherent part of his system of natural liberty. The role of the state- accordingly- was largely the "night watchman". State instilled law and order, provided for defense and maintained the value of the currency. (Reisman, David. A., 1998, p.358). This was the determined frame of the role of the state, which gave pace for the liberal choice of the individual that was emphasized afterwards by Hume, Mill and then Nozick and Rawls.

State intervention in the economy in the early liberal context of the twentieth century was not rejected. However, constitutional limits were put on governments to limit state's protectionists activities (Miller, Eugene F., 2001, p.42).

The same thought was emphasized by Hayek through a liberal neoclassical model in his book "The Road to Serfdom", where he denounced collectivism and state intervention and demonstrated that state planners would worsen the welfare of the society if they attempted to replace markets. Therefore, the economy should be characterized by individual tasks and by technology and firms. (Hayek, Friedrich A.,2001, pp.40.45). The liberal neo-classical model that he employed in defending the market system is related to decentralization of production and exchange. Competitive market systems could generate greater individual liberties and choices (Helm, Dieter, 1986, p. 3).

The liberalism of the twentieth century emphasized freedom through welfare, where liberals - according to Friedman- put their reliance primarily 
upon the state rather than on private voluntary arrangements (Milton Friedman, 2013, pp.6.10). Liberalism as a movement supports economic freedom through laissez-faire as a means of reducing the role of the state in economic affairs. And it needs economic organizations that organize economic activities in a largely free market and private enterprises, which relates the right of the individual with the right of the communion, society, and the common interest (Mill, John Stewart,2011, pp.23-24). This formulation was later expressed that society and the individual's interests do not coincide. Keynesians' liberalism perceived laissez -faire mechanism as not intelligent, not just and not delivering goods (Dillard, Dudley,1948, pp.171-177), which contradicts with the stage of neoliberalism, which takes the freedom of the individual as the ultimate goal in determining social arrangements (Friedman, Milton,1961, p.12). Neoliberalists state that the role of market is conforming to essential and universal principles, therefore opposed economic regulations, state spending on public goods and service provisions, because they do not infuse economic or political considerations into economic activity. In addition to the former, those states which adopted central planning and state managed capitalism often failed to create internationally competitive business. Any concerns about the negative side of neoliberal reforms were erased with the emergence of the information technology in the ninetieth century. Intellectual products moved to upper wages, while physical production moved to low wages. The Western economies ceded dominance in resource extraction and low technology production (Centino, Miguel A.,2012, pp.321.328)

\section{Creating consensus over the economic role of the state}

The consensus over the economic role of the state witnessed several stages. The first stage was the post war consensus over the welfare state as opposed to the warfare state of Hitler. It demonstrated the new social partnership between the capital, labour, the state, and the market. This vision 
failed and was feared to lead to nationalism. The second stage was the private and public ownership. Some parts of the economy, from a macroeconomic perspective, were seen to be under state control. The third stage is about coordinating the macroeconomic role of the state through a high-level employment (Helm, Dieter,1951, p.14).

Another perspective to reach consensus between the state economic role and market advocates was through a democratic version. Hayek, Polany and Keynes, promoted three political impulses about the capacity of the state to intervene successfully and reshape the market. The Impulses evolve around technocratic, democratic, and neoliberal impulses (Rahman, Sabeel, 2011, p.265). Policy makers renewed the debate over the economic role of the state after the 2008 economic crises and the introduction of a more active government role. It was perceived that the administration adopts the broader Keynesian concept of the relationship between the state, market and society through managerial liberalism that promotes the laissez-faire economy through the intervention of a technocratic state. This would not constrain individual initiative but would create an environment in which such initiative would be productive. Accordingly, the role of the state is to initiate activities that the individual would not take if the state does not make it (Keynes, Meynard J.,2004, p.16). On the other hand, Karl Polany's argument on the neo-liberal laissez-faire economics differed from Keynes in two aspects: The goal of the state action is not to optimize of market process, but to hold market forces to account and to invest in political agencies not in technocratic expert bodies, and to establish a broader democratic society. Polany focused on mobilizing democratic citizens who could build a modern market, that functions within the scope of political agency and according to the social order. Thus, the market should be socially constructed and act as an adjunct to the society. 
Therefore, the state should actively engage in shaping market dynamics. (Rahman, Sabeel,2011, pp.276-278)

\section{The economic role of the state in providing goods}

Providing public goods has been the role type of the state involvement in the economy. The past seventy years have shown benefits and limitations of state actions in the economic sphere. Government actions have helped develop and deliver public goods, however resulting as well in non-efficient outcome. Sometimes government succeeded to adapt to the changing political and economic landscape, while failed in other instances (World Bank Report, 1977, p.1)

During the inter-war period, the state role developed to social assistance to overcome increased unemployment, which differed dramatically in England during Tatcher's government, where the role of the state was curtailed to allow for space for the individual. (Helm, Dieter, 1951, p.15). The state provision of goods and services has varied resulting in different public private mixes. In bundled systems a variety of public goods: private and collective, subsidized, and unsubsidized, competitive, and monopolistic, are all taken by a single public provider ${ }^{\text {(Krader, Lawrence, 1968, p.46) }}$. But when services are unbundled, it become possible to distinguish between goods and activities that could be financed and delivered entirely through private markets, and those whose delivery and finance should remain with government institutions but could privately delivered through contracting and similar mechanisms. Technology and innovation represent a new opportunity for competition among the goods and services that could be privately delivered ${ }^{(1)}$ (World Bank Report, 1997, p.12-14). Microcomputer software is an example of public good that is produced in the private sector. Once the program is written, additional users can copy the program, making it available to additional users at no cost to existing users, and it is also nonexcludable (Samuelson, Paul A.,1954, pp. 387-388). Thus, 
the private market has been successful in producing this public good, and in the provision of incentives to satisfy consumer demands at low cost. We can argue then, that public goods theory does not comprehensively explain why the goods produced by the government are public goods. A public good, as defined by Samuelson, is a good that once produced, can be consumed by an additional consumer at no additional cost (Samuelson, Paul A. 1954, p.391). Consumers cannot be excluded from consuming the public good, because it is jointness in consumption, nonrivalry and nonexcludable. The former characteristics imply that it could not be produced by the private sector or may not be produced at all. However, production of public goods by the government does not - according to Randall Holcombe- justify that the government should be the only producer of it, nor that the state produces it in an efficient way. If there are incentives, such as low cost, many employers may have an interest in producing it. So, an opportunity exists that public goods could be produced by private sector (Holcombe, Randall G., 1997, p.32) Another important aspect of the public goods theory is the individual preference of public goods. Once the public good is there, every individual seeks to benefit from it without having to share in its cost. (Johansen, Leif, 1977, pp.147.148)

Other empirical studies on producing goods by the government confirm that they are private goods, such as certain legislations (Holcombe, Randall G., 1997). But the government still allocate resources for providing both public and private goods (Sandmo, Angar,1973, p.518). In that regard, Samuelson argues that the reason that they are produced by the government is the market failure to allocate resources for the production of public goods (Samuelson, Paul A., 1954, p.388) (3) In recent years, states have come under pressure for providing new goods

\footnotetext{
(3) Public goods are non- rival marginal consumption, meaning consumption by one user does not reduce the supply available for others. Public goods are also non-excludable, for users cannot be prevented from consuming the good. These characteristics made it difficult to charge for the consumption of public goods, and thus - according to the classical approach-
} 
that are neither independent nor new in essence such as technology products. Sharing state's responsibilities with the society was perceived a solution for the provision of such services and for matching the state's role with its capabilities. It aims also to strengthen state capabilities by increasing the ability of its institutions to benefit from the technological developments, which have created - among innovations- new opportunities for competitive private providers of goods and services traditionally confined to the state. (World Bank Report, 1997, pp.36.38).

\section{The influences of the liberal schools of thought on the economic role of the state and private sector in Egypt.}

The economic liberal trends could be identified in Egypt since the nineteenth century. Egypt was influenced by the liberalization process of the first industrial revolution, which have impacted the modernization process in Egypt in a paradox way: The first incident was the French occupation 19781801 and the second incident was the rule of Mohammed Ali Pasha (18051848). Those influences resulted in socio-economic changes and in the modernization of land and tariff legislations in Egypt. The struggle was not on building factories but to on acquiring and maintaining control of the land during the eighteenth and nineteenth century. The prevailing system of property was exclusive control of individuals over the land. (Cuno, Kenneth M., 1980, pp.245,246)

Egypt embraced industrialization policies as well in the mid of the ninetieth century earlier than any other Arab country. It achieved higher rates of manufacturing growth. The manufacturing process was similar to

private suppliers might lack the incentive to supply them. Countries with low state capabilities focus more on basic functions that concentrate on the provision of essential public goods such as safe water, controlling diseases, basic education. However, recent social and economic developments have emphasized new additional public goods like technology and related infrastructure. (World Bank Report, The State in a changing World, 1997). 
developed countries. And it also had committed itself to free trade treaties since 1838. The manufacturing value-added included factory production, construction, and mining production, as well as handicraft production. However, agrarian interests and growing influence of landowners determined the Egyptian industrial policies. (Karakoc, Ulas et.al., 2017, pp.4-5)

The transition from a subsistence economy to a complex economy was slow in the beginning of 1800 due to the strong ties that bind the individual to the village or tribe. In addition to the difficulties of breaking up with traditional feudal, communal, or tribal structures, which prevented the labor becoming a mobile commodity. Mohammed Ali (1805-1849) planned to make the transition to a complex, modern economy through improving land tenure, irrigation and tax system and communication. His ambitions to reestablish a strong state halted the development towards land ownership. Peasants cultivated what the state decided, particularly cotton in collaboration with the state on a commercial scale for export. Also, industry, trade and investment were forced and monopolized by the state. (Issawi, Charles, 1961, pp.3-6) The Anglo- Turkish Convention that was enforced on Mohammed Ali after his defeat allowed for a bigger role of the foreign private sector to buy, sell, and trade. After 1882 Egypt was integrated in the world economic system through agricultural products. (Issawi, Charles, 1961, p.8).

Inspite of developments that Egypt had witnessed in the beginning of the twentieth century, Egypt still represented a case of agricultural specialization, particularly in cotton cultivation. (شلبي، علي 2006 ص ص 24 - 31 (3)

And 35\% of the labor force were employed in the textile and clothing industry. (Karakoc, Ulas et.al.,2017, p.7). About 750.000 were employed (less than 5\% of the population) in other industrial activities such as building and mining. The reasons for the limited industrial activities post the first world war period were mainly the low purchasing power and the depressed living standard of 
the majority of the Egyptians, the lack of cheap fuel, limited raw materials, shortage of educated and skilled labour, the lack of tariff protection and the dearth of capital that was attracted to the agricultural sector and owned by the landlords. (Mountjoy, Alan, The Development of Industry in Egypt, Economic Geography, Vol.28., No.3, 1952, p.10). By the beginning of the twentieth century the manufacturing and mining industry accounted only for $5 \%$ of the gross national product. Starting from 1927 national and foreign private sector emerged in food-processing, textile and building material.). The government supported 256.000 establishments which hired up to ten persons until 1952, and credit had been advance through the "Industrial Bank". Manufacturing had been left to the private enterprises until 1954. Several Egyptian companies were established between the period 1924-1948 such as "Misr Cotton Ginning Company, Misr Cotton Spinning and Weaving Company, Misr Linen Company, Misr Insurance Company, Misr Bank, Misr Oil Manufacturing and Trading Company, Misr Aviation Company and Misr Transport and River Navigation

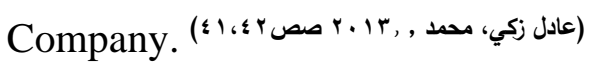

Though the progress in the manufacturing sector Egypt had witnessed since 1927, this was not reflected in the in increasing exports, due to limited capita, semi-skilled labor, small scale of manufacturing mechanicals and the currency failure in providing support for domestic manufacturing since it was linked to gold. (Karakoc, Ulas et.al.., 2017, p.8)

Starting from 1954 the government share in the industrial sector has increased to reach $64 \%$ by the end of 1958 though the increase in urban population. (Issawi, Charles, 1961, pp.17-19). The commitment to a "statism model" had characterized the economic development model. Statism is a developmental model that ascribes a dominant role for the state in the economy. It is seen as embedded with political claims and ideologies such as 
nationalism and socialism. It compensated for the relatively weak role played by private businesses by developing a powerful capacity to intervene in the economy in the absence of administrative capacity to sustain a statist project. Statism is perceived as contested approach where different social forces seek to benefit from the state in implementing different development projects. As a result, private gross investment levels decreased from 112 million L.E. in 1950 to 38 million L.E. in 1956 though the encouragement of the political regime for foreign and private ownership of new industries. (Joya, 2020, pp39.41) Thus, the existence of private enterprises was not prohibited until late 50s, but its role was not as important as the role of the public sector which expanded significantly in $1961^{\text {(Joya, A. 2020, p.43) }}$ and (Mohamed, Ahmed Ezzeldin, 2014).

Though the statism model, the post 1954 marked a failure in disintegrating Egypt's economy from the influences of the world capitalist economy. A neo-colonization model reflected in multinational corporations dominated the economic activities despite Gamal Abdel Nasser's efforts to introduce socialist principles in Egypt during the period 1961-1967. p.25 (Chaichian, Mohammed A., 1988, p.25)

Capitalist production had become a dominant factor in the social formation in Egypt and the intervention of the state aimed at promoting industrialization through weakening the power of the landowners and the foreign enterprises by forcing them to redirect their capital investment into the industrial sector and transforming an agrarian economy into an independent industrial capitalism. (Chaichian, Mohammed A., 1988, p.35). This required the nationalization of private property without suppressing the right to it. 6 million L.E. out of 45 million L.E invested in the land were taken to be invested in the industry by the state. Still permanent labor in agriculture continued in rural areas, whereas those who were not employed in the agricultural sector were casual labor "Tarahil Labor, who did not have a stable 
income and could not be employed in the limited industrial sector, though they have migrated to the major urban centers, namely Cairo and Alexandria. So, urbanization did not refer to industrialization in Egypt post 1954 (Chaichian, Mohammed A., 1988, pp.36,41).

The seventieth years marked a liberal shift in state policies introduced by Anwar Al Sadat towards market economy, namely the "infitah" or "open door "policy' and the facilitation of a larger role of the private sector. Sadat era proved the inadequacy of nationalization without abolishing private property rights. The open-door policy adopted by Sadat aimed at attracting Western capital investment, in addition to foreign policy that matched the transition to more integration into the world economy. One important characteristic of the open-door policy was the fading welfare dimension of Nasser's rule. His reorientation program included: prosperity, reconstruction, and democracy. This was followed by subsidy reduction, the rise in prices, the increase in imported goods and the creation of a new open-door consumer -oriented class. Also, the emphasis of the role of the private sector built in the open-door policy economy has threatened the role of the public sector. (William, Raymond, 1981, pp.380,381). The changes in the structure of the Egyptian industry were not major. The main industries remined in in agricultural projects like food processing, and some manufacturing projects such as miming, building materials and electronics. The annual growth rates for manufactured goods by the private sector for the period 1973 and 1977 accounted for 5\% and $10.6 \%$ respectively. (Joya, A.2020, pp 30,55)

"Infitah" meant as well public private partnership and engaging with foreign capital through the state bourgeoisie. This resulted in the increase of growth rates which averaged according to the World Bank $6.7 \%$ and an increase in per capita income by an average of 4.3\% between 1971-1980 compared to $2.3 \%$ between 1961-1970. The latter improvements were said 
to be not due to liberalization policies, but of the increase of Suez Canal revenues, the increase in oil production in Sinai and the increase in remittances from Egyptian migrant workers in the Gulf oil industries. (Joya, A. 2020, p.63). Hence, though the open-door policy, the state was still considered to be the dominant economic sector responsible for the majority of economic activities.

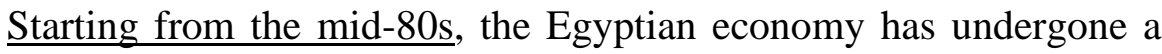
dramatic process of economic liberalization. During this period the Egyptian economy was burdened with high levels of external debt resulting from trade deficits and aggressive monetary policies pursued by the US Federal Reserve during the period 1979-1981 and the new development project of the financial institutions "the Washington Consensus" which imposed a neo liberal model on Egypt and the global south. The model argument assumed that economic liberalization would restrain state intervention in the economy and provide sufficient conditions for individuals 'freedom. The model included reforming the tax system to reduce the economic cost of doing business, liberalization of trade and foreign direct investment to enhance comparative advantage and open the economy to foreign investors, and deregulation of economic activities to increase business competitiveness This also led to transfer public services and assets to the private sphere according to an entrepreneurial logic. (Joya, A., p.69) and (Najarajan, K.V., May 2013) and (Alissa, Sufyan, 2007).

Since the early nineties until 2021, the role of the government in Egypt has focused on the provision of a business - enabling institutional environment, creating markets, safeguarding property rights, and protecting the vulnerable more than on the direct provision of goods and services. Several efforts and initiatives have been taken since then, albeit with varying degrees of success. 
The private sector in Egypt played an integral and increasing role in the economy providing a share of $60 \%$ of the GDP and $74 \%$ of employment in 2017. Its activities are also diversified with the manufacturing, agriculture, retail trade and construction sectors as the major contributors to private sector output. The retail trade and manufacturing sectors in particular contribute to private sector GDP (40\%) significantly and account for $73 \%$ of the total number of firms. (European Bank for Reconstruction and Development,2017, p.3).

Figure 1. Gross fixed capital formation, private sector (\% of GDP)

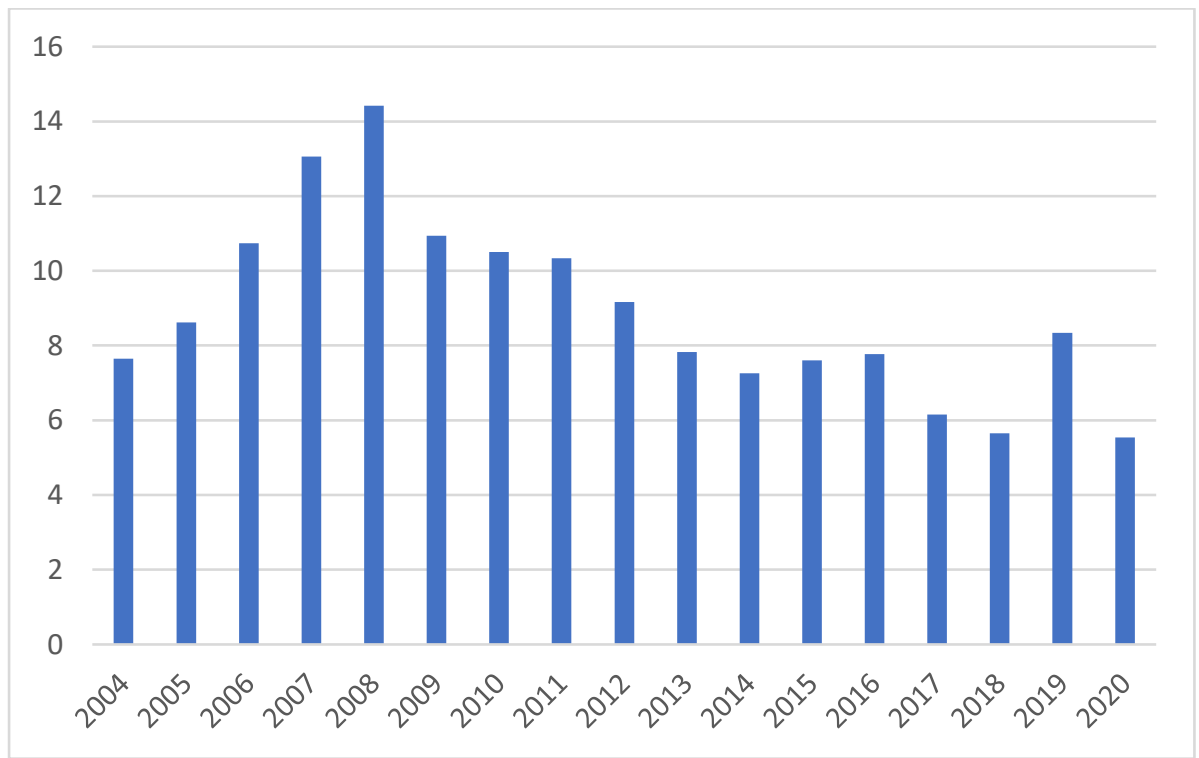

Source: World Development Indicators

The above figure shows that gross private fixed capital formation as a percent of GDP remains low in Egypt with an average of $8.9 \%$ during the period from 2004 to 2020, peaking at $14.4 \%$ in 2008 then declining reaching $5.6 \%$ in 2018 and 5.5\% in 2020. It is worth noting that average private Gross fixed capital formation in low- and middle-income countries is around 25\%, that is more than three times its percent in Egypt.

Since the launch of the Egyptian Information Society Initiative (EISI) in 2004 , the state has encouraged the private sector to benefit from the third 
industrial revolution manifested in in information and communication technologies and allocated 70 million L.E for open source and mobile application for delivering public services and engaged 549 SMEs in the initiative. It also certified 450 ICT clubs in 2009. From 2015-2016 almost 245 ICT companies were established in Egypt with a total capital of 130 million L.E. the ICT products' contribution to GDP was 65 billion L.E. in FY 20142015. The Ministry of Communication and Information Technology plans to increase ICT products' contribution to the GDP to 195 billion L.E. in FY 2020-2021. Concerning the ICT products' contribution to the export sector it was less than $0.5 \%$ of total goods'exports during the period 2008-2013 and increased to $2.8 \%$ in 2014. (El Nawawy, Mohamed Fouad et.al., 2017, pp.6,7)

\section{Part II. The 4.0 outcomes: Re- shifting the focus to the individual}

New technologies bound individuals with each other. It could make the individual have more control over the economic production. (Knight, Frank H.,1941, p.818) However, utilizing new technologies, such as the products of the "Fourth Industrial Revolution" 4.0 confronts the individual with a vast array of challenges

The term "Fourth Industrial Revolution "4.0", has been used to analyze the impact of emerging technologies on every aspect of human development: from evolving social norms and national political attitudes to economic development and international relations. It affirms that technological change as a driver of transformation to all parts of society. It is like other revolutions, a revolution in the system that surrounds us, and a complex interplay between humans and technology (Philbeck, Thomas and Al, 2019, p.17). Over the past twenty years, digitalization has contributed to improving service delivery. It has created connections between the individual, state, and the society in the policy cycle, due to the daily operations of the government. 
Individuals took advantage of the technology and benefited from the logic of solidarity such as in the interest groups. Therefore, Information and Communication Technology (ICT) have sparked the individualization of economic and political representation (Gao, Xiang, 2020, pp.3-4). The implications of the revolution 4.0 on the individual, state and society is multifold: innovations such as AI and Robotics, Internet of Things (IoT), 3D printing and Drones have implications on unemployment and disruption of traditional businesses, and sometimes the rise of monopolies. ${ }^{(4)}$ In analyzing the implications of revolution 4.0, the center of gravity shifts in the direction of the individual and the innovations owned by high-tech companies (Teck-Boon Tan, Wu Shang-Su, Rajaratnam, 2017, p.19), which would influence government policies and roles and the provision of advanced technology as a public good.

Therefore, revolution 4.0 has brought to the fore the debate about the economic role of the state versus the role of the individual.

The impact of 4.0 on the society and economics is founded on principles, around mutual empowerment of state, society, and individuals. It also means that 4.0 products could eliminate the coercive power of the state, albeit state power will be still important throughout the 4.0 process, especially in setting laws, regulations and rules that constitute an important part of its institutional environment (Philbeck, Thomas and Al,2019, p.21). And if the state plays a role in shaping the institutional environment for entrepreneurship, businesses, and the rest of the economy (World Bank Report, 1997, p.40), the role of the individual in economic life includes benefits the state in both enterprise and official institutions. The modern economic order is characterized by "an enterprise economy", where technology is directing more specialization. Individuals are specialized - not only - in making certain products, but in performing detailed 
operations (Knight, Frank H., 1941, p.820). The making of a single product in the era of revolution 4.0 may or may not require the cooperation of a large number of individuals. Thus, formal state activities should direct individual activities related to 4.0 products, which could have profound effects on economic outcomes.

The role of individual in shaping the economic order was conceptualized in several neo-classical economic theories, such as Hayek's "Individualism and Economic Order" (Hayek, F.V., 1948, p.8) Individualism, according to Hayek, is primarily a theory of society, which rejects the common belief that individualism postulates the existence of isolated, selfcontained individuals. The belief that individualism approves and encourages human selfishness is one of the main reasons why so many people reject it (Hayek, F.V., 1948, p.11).

Many institutions are a result of combined effects of individual actions and have arisen and are functioned without a designing and directing authority, as Adam Ferguson expressed it, "nations stumble upon establishments, which are the result of human action but not the result of human design". (Ferguson, Adam, 1995, pp.10-14). The individual knowledge is important for the economy. Hence, economic decisions can be left to the individual. And since technology constitute an economic issue in itself, decentralization is needed to ensure the use of the individual knowledge timely and geographically (Hayek, F. A, 1945, p.12). Accordingly, the economy is the scope of free activity, and the extent of effective individual liberty. And effective liberty should be free form interference by other individuals or agents of society. (Knight, Frank H., 1941, p.826). In the same context, studies found a correlation between individualism, the enterprise market and economic development. Open market is considered the path to preserve and increase the liberty and the economic attributes of the individual: his wants, the resources 
that he owns and controls and his knowledge of productive techniques (Eckstein, Alexander, 1958, p.85). So, the scope of the individual activities in economic life is reflected in the relation between economic democracy and collectivism. And maximum freedom is a prerequisite for innovations in technology, and maximum competition that conduct enterprise economy in a way near to the ideal pattern of economic theory. In the context of individual liberty, 4.0 implies a different state-society relationship. Social and economic responsibilities will be distributed among individuals. Individuals can connect through smart systems (Internet of Things (IoT) and blockchain systems) with minimum government and formal authority intervention (O'Halloran, Derek, and Al, 2015) (5)

(5) Examining the mutual empowerment principle, the consequences of one of the 4.0 digitalization advances are enormous. More than $50 \%$ of the world people are now online, and approximately one million each day go online for the first time. Two third of the global population own a mobile devise. Digital technology is bringing many social and economic benefits to much of the global population (Global Risk Report, $15^{\text {th }}$ Edition, 2020). Crossborder flow of technology, ideas, news, and data have grown rapidly for more than a third of the increase in global GDP in 2014 to about 2,8 trillion US\$, promoting some researchers to call it the $4^{\text {th }}$ era of digital globalization (Digital Evolution Index $\{$ DEI $\}$, Digital Planet Report, 2017). Digital flows are responsible for more GDP growth than trade in traditional goods. AI, IoT, big data and business models such as "the sharing economy" are changing the way we conduct business. It could affect $50 \%$ of the world economy. For example, and based on their stock prices, APPLE, MICROSOFT, FACEBOOK, ALPHABET AND AMAZON, were considered the five most valuable companies in the world. These companies dominate the big part of the world digital market. This requires according to DEI Index, trust in the digital environment, and the quality of users' experience attitude towards key institutions (Ibid.).

But digital markets are uneven. Level of economic development and political relations play an important role in shaping the digital industry and its markets. With the world's largest internet user population (721 M), China has a parallel digital market, because so many of the major global players have no presence. Also, India with its $462 \mathrm{M}$ internet population users operates in multi - infrastructure. The European Union has $412 \mathrm{M}$ internet users. (World Economic Forum, Digital Economy and New Value Creation, 2017). Around the world digitalization is far from uniform. 


\section{Part III. Matching state capabilities with its policies: Egypt's policies in embracing the framework and conditions of 4.0.}

Recent technological developments of digitalization, smart automation and software have encouraged countries and industries to set up visions and plans for economic growth and to strengthen their competitive positions.

The extension of the connectivity enabled by the IoT, and digitalization can integrate physical systems, thus, coordinated actions and decisions based on collaboration can be implemented quickly and accurately and compress time and space. Products will be connected and commoditized through IoT (O'Halloran, Derek, and Al., 2015).

Empirically, digital transformation is gaining increasing emphasis on the economic global agenda. Solow designed a mathematical model to work out what increases output in a developed economy. "It turned out that by far the largest contribution came from something that can't be explained by population growth, a labor supply increase or a growing stock of equipment," (Solow, R. ,1945, p.65.). The largest contribution comes from technological innovation. Countries abilities to create, absorb and use new technology lead to sustained growth (Solow, R. ,1945, p.94). Solow growth model explains differences in per capita income levels based on differences in both, the growth rate of technology and human capital. (Gaertner, Manfred 2009, pp.37.39). Policies designed to promote economic growth target the adoption of the state-of-the-art technology, and human capital development in education and training to use the technology.

Thus, many countries, including Egypt, have set their National Digital transformation strategy that realizes the importance of the digital transformation to achieve inclusive and sustainable growth (OECD,2017). An integral part of Egypt's Sustainable Development Strategy (SDS), known as 
Egypt vision 2030 is to transform the economy into a knowledge-based economy ${ }^{(6)}$. Short term and medium-term plans and policies were articulated to speed up the transformation process. The total planned investment in the medium plan 2018/2019 -2021/2022 is L.E 5.8 trillion, 58\% of that figure represent investment by the private and cooperative sector.

\section{Government policies, initiatives, and its implications for a}

\section{knowledge-based economy}

Three main avenues for policy actions are identified in the Egyptian context: First to build a supportive institutional environment that spurs competition, innovation, and investment Second, to provide an upgraded ICT infrastructure to encourage ICT related industries and the use of E commerce. Third, to provide the necessary training and skill development to allow the inclusion of all in the digital economy.

Since 2004, Egypt has realized the importance of ICT in economic and social development in drafting the "Egyptian Information Society Initiative 2004". The Initiative emphasized the role of the private sector, the individuals and civil society aside with official institutions in setting the framework for an ICT society (e-health, e-learning, e-business, e-culture and e-government). The initiative was followed by issuing the "National ICT Strategy 2004-2006' to support the transition to the digital information

\footnotetext{
(6) Several organizations have attempted to define what constitutes a knowledge - based economy (for example the OECD, APEC, and the World Bank). The common factor between the different definitions is that they all revolve around the reliance of the economy on the production and use of ideas, knowledge, innovation as well as technology as engines for growth. According to the World Bank there are four pillars for a knowledge based economy 1- An economic and institutional regime to provide incentives for the efficient use of existing and new entrepreneurship; 2- education and training to create, share, and use knowledge efficiently; 3- innovation and technological adoption of firms, research centers, universities, consultants and other organizations to tap into the growing stock of global knowledge, assimilate and adapt it to local needs, and create new technology; 4- Information and communication technology (ICT) infrastructure to facilitate the effective creation, dissemination, and processing of information.
} 
society that addresses all sectors including the economy. (Kamel, Sherif, 2007, pp.845847)

In 2016 the Egyptian government has drafted strategies that included formal projects and initiatives. The aim of examining those strategies is to understand the consensus -types between the state and other actors, as well as examining how the state perceive its role in embracing the economic growth opportunities of the 4.0. And in October 2016, the Supreme Council for Investment, was established and headed by the president of Egypt to follow up on the implementation of the country's investment vision, and to adopt radical solutions to investors' problems particularly those emerging from conflicts in laws and regulations related to investment climate and free zones. Furthermore, in 2017 a new investment law was drafted: Investment Law Number 72,2017". The law provides new safeguards for investors as well as general and special incentives to encourage significant and targeted investments ${ }^{(7)}$. It dedicates a full chapter to potential investments in technology zones identifying opportunities, incentives, and exemptions. It is worth mentioning that the Government Plan 2018/ 2022 aims at expanding the number of technology zones and science parks. In that context, The Ministry of ICT works in partnership with the various stakeholders and technology innovators to introduce integrated smart and scalable solutions to support such mega projects. In 2016, "Silicon Waha", a leading stock company, was founded with the aim of creating a series of specialized business and technology parks across 2nd tier cities in Egyptian governorates. $^{(8)}$ Another project was launched in 2020 which is Egypt's

\footnotetext{
(7) Deductions from taxable net profits of $30 \%$ to $50 \%$ off investment costs investment in some sectors. For example, investment in ICT related industries qualify for the $30 \%$ discount while investments in Suez Canal economic zone and the economic zone of the golden triangle qualify for the 50\% discount. (Ministry of Planning, medium Plan 2018/19-2021/22)

(8) The company is committed to providing the essential elements necessary for the dissemination of technology in businesses, and to encourage the development of talent pools
} 
knowledge city, located within the administrative capital. It will focus its research on activities which will serve the needs of these smart cities.

As part of strengthening the institutional framework, several branches for the General Authority for Investment and free zones (GAFI) were opened in several governorates to provide digital services and facilitate interactions with investors to enable a financial legal transition towards digitalization, the Ministry of Finance in cooperation with the Ministry of Investment issued the e-Signature Law. With respect to efforts to speed up the digital transformation process the e-Signature Law was enacted in 2004 to enable a financial legal transition towards digitalization and the Consumer Protection Law was enacted in 2006 and modified in 2018, have helped to pave the ground to engage in e-commerce.

In December 2017, the National e- Commerce Strategy was launched in cooperation with the United Nations Conference on Trade and Development (UNCTAD,2017) to identify the potentials and challenges of ecommerce in Egypt (Ministry of ICT). Moreover, the Egyptian Supreme Cybersecurity Council (ESCC) launched National Cybersecurity Strategy (2017-2021) to provide a safe and secure environment that would enable various sectors to deliver integrated e-services ${ }^{(9)}$.

In March 2019, The Central Bank of Egypt (CBE) has launched its "FinTech and Innovation Integrated Strategy" to promote Egypt's FinTech

across various industries. These technology zones are located one in Borg Al Arab city, 10th of Ramadan city, and New Asuit, New Aswan and Beni Suef governorates. The stakeholders are state -owned organizations: Ministry of Communications and Information Technology (MCIT), Information Technology Industry Development Agency (ITIDA), New Urban Communities Authority (NUCA) and The National Telecom Regulatory Authority (NTRA). (https://itida.gov.eg/English/Pages/Silicon-Waha.aspx) .

(9) This is in line with article (31) of the Egyptian Constitution, Jan 2014 that acknowledges that security of cyberspace is an integral part of the economic system and national security and that the State shall take the necessary measures to preserve it. (Egyptian Supreme Cybersecurity Council,2017) 
ecosystem and position Egypt as the regionally recognized FinTech hub ${ }^{(10)}$. The CBE has also committed up to EGP 1 billion towards the Innovation Fund-of-Funds along with major institutions focusing on FinTech investments ${ }^{11}$ to encourage FinTech start-ups, invest in youth talent and fund the necessary infrastructure to spur new FinTech trends (https://fintech.cbe.org.eg/Home/fund?en). This is all evidence on institutional efforts to provide an enabling environment to mobilize investments in Fintech and facilitate the digital transformation.

In 2020, The Egyptian Digital Transformation Plan was drafted aiming at building a digital economy. The Plan consists of three pillars: the digital transformation, digital skill, and digital innovation. The digital infrastructure includes the speed of the internet, the ICT cable infrastructure and digital service centers such as post offices. The legislative infrastructure consists of laws such as the e-Signature law, the Patent Rights law, the Cyber Crime law, and the Customer Protection law.

The Digital Plan included an initiative that reflects a consensus between the state as an initiator and the society. The "Digital Opportunity "initiative, which is managed by the Information Technology Industry Development Agency (ITIDA), ${ }^{(12)}$ provided 33 opportunities for small and medium enterprises with a total cost of 90 million L.E. The Agency will supervise the training of 500 youths in areas of AI and machine learning.

(10) According to the CBE, each one EGP invested in FinTech contributes EGP1.6 to GDP, and each job created in FinTech supports 5.6 other jobs.

(11) Fund-of-Funds investment vehicle is established along with major institutions focusing on Technology \& FinTech investments for the purpose of 1- Launching an independent investment catalyst vehicle promoting investments into Venture Capital funds focusing on Tech/FinTech sectors. 2- Capitalizing on the expertise and strengths of partner institutions co-investing with $\mathrm{CBE}$ in creating a sustainable and independent investment platform mobilizing funding and expertise to support the growth of the eco-system (Central Bank of Egypt website)

(12) ITIDA is a government entity that is responsible for facilitating the contribution of small and medium enterprises in the implementation of digital transformation projects. 
(http://www.digitalopportunity.itida.gov.eg/Arab\%E2\%80\%A6/Pages/Abou tUs.aspx $)$. The training will be delivered by private companies. The main initiatives and its digital platforms are state -driven.

More recently, the Ministry of Defense has established the College of Secured and Smart Versions according to the law No 232/2021. The aim of the college is to provide technical solutions for data processing for digitalizing public services and needs. The managing board consists only government institutions. (Official Newspaper, No.22, June,2021, pp.5-15)

\section{An assessment of the current state of the Egyptian knowledge}

- based economy

In order to identify the performance of state and private sector institutions to establish a knowledge-based economy, we assessed international indices.

Table 1 illustrates Egypt's recent positions and ranks rank in several of international indices, which are indicators of Egypt's position compared to other countries in various aspects, such as the transformation into a knowledge -based economy, the ability to sustainably compete in the world economy and the ease of doing business. Table 1. shows Egypt ranks fairly low in all the international indices cited. Despite the strategic objective set by the medium Plan 2018/19-2021/2022 for Egypt to be among the top 50 countries in terms of integration in the Knowledge economy, Egypt ranks 97 out of 144 countries in the knowledge Economy index KEI (2012) ${ }^{(13)}$.

(13) (KEI) is an aggregate index, published by the World bank and was discontinued in 2012. The index reflets overall preparedness to compete in the knowledge economy and is based on the simple average of four sub-indices which represent the four pillars of the knowledge economy. 
The Impact of the 4th Industrial Revolution Outcomes on the Economic Role of the State Egypt as a Case Study (2013-2021)

Table 1: Egypt's scores and ranking in 2019 in a number of key international indices

\begin{tabular}{|l|c|lr|}
\hline \multicolumn{1}{|c|}{ Index } & $\begin{array}{c}\text { Egypt's } \\
\text { Score }\end{array}$ & $\begin{array}{c}\text { Egypt's Rank / Total } \\
\text { number of Countries } \\
\text { (year) }\end{array}$ \\
\hline Knowledge Economy Index $^{14}$ & 3.11 & $97 / 144$ & $(2018)$ \\
\hline${\text { Global Competitiveness index } 4.0^{15}}^{15}$ & 55 & $93 / 141$ \\
\hline Ease of Doing Business $^{16}$ & 60.1 & $114 / 190$ \\
\hline
\end{tabular}

Source: compiled from different sources as indicated by the corresponding footnote

Figure 1: The Evolution of Egypt's Rank in the Global

\section{Competitiveness Index}

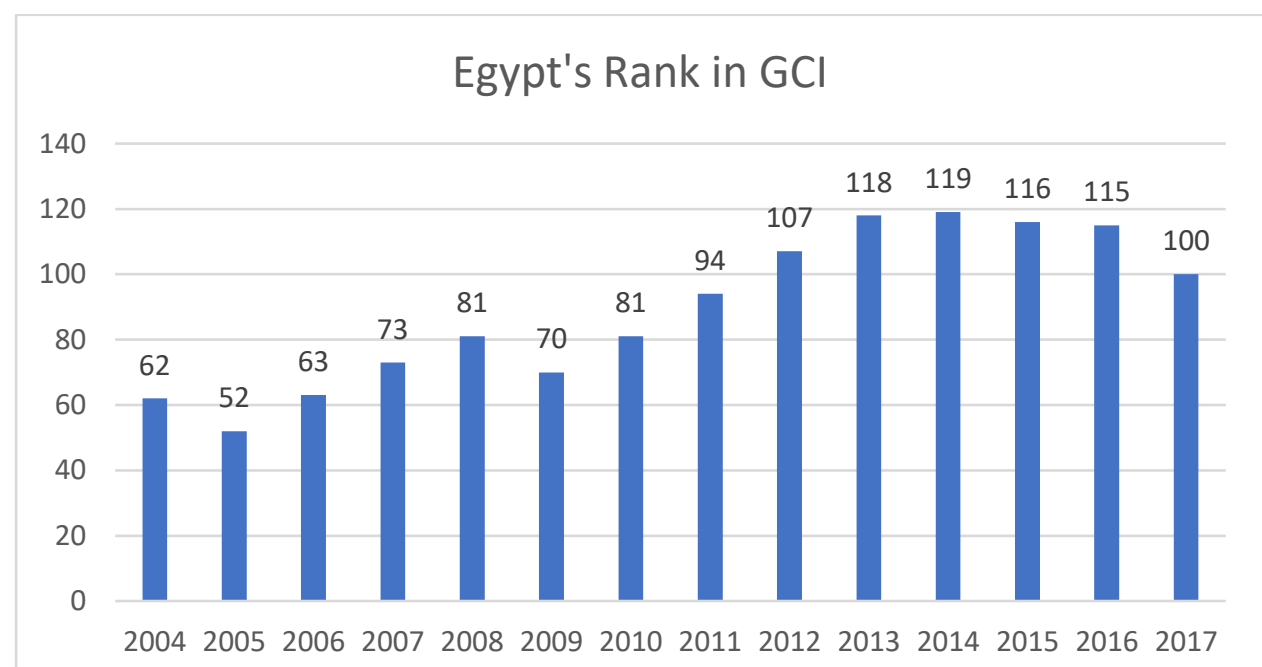

Source: Ministry of Planning and Economic Development, Medium Plan 2018/19-2021/22

\footnotetext{
(14) $\mathrm{https://knoema.com/aomssce/knowledge-economy}$ index?location=Egypt\%2C\%20Arab\%20Rep.\&indicator=Knowledge\%20Economy\%20Ind ex ( KEI) (Ministry of Planning and Economic Development medium term plan2018/192021/22)

(15) (World Economic Forum,2019)

(16) (World Bank ,2019)
} 
Figure 1. indicates the evolution of Egypt's rank Global Competitiveness Index (GCI) ${ }^{(17)}$ and shows that Egypt's rank deteriorated from the 52nd position in 2005 to the 119th position in 2014. A gradual improvement occurred in the following three years when Egypt scored 3.9/10 and ranked 100 /137 in 2017. The 2019 edition of Global Competitiveness Report assesses 140 economies. The report is made up of 98 variables, from a combination of data from international organizations as well as from the World Economic Forum's Executive Opinion Survey. The variables are organized into twelve pillars with the most important including: institutions; infrastructure; ICT adoption; macroeconomic stability; health; skills; product market; labour market; financial system; market size; business dynamism; and innovation capability. The GCI varies between 1 and 100, higher average score means higher degree of competitiveness. In the 2018 edition, the World Economic Forum introduced a new methodology, aiming to integrate the aspects of the 4th Industrial Revolution into the definition of competitiveness. It emphasizes the role of human capital, innovation, resilience, and agility, as not only drivers but also defining features of economic success in the 4th Industrial Revolution (Global Competitiveness Index,2019).

Table 2 shows the evolution of Egypt's score and rank in the Knowledge Economy Index (KEI) and records a decline in the rank and score

(17) The Global Competitiveness Index (GCI) is a compound index published by the world Economic forum. It is made up of 12 pillars that compare countries: Institutions; Infrastructure; ICT adoption; Macroeconomic stability; Health; Skills; Product market; Labour market; Financial system; Market size; Business dynamism; and Innovation capability The index is based on three main sub- indices: 1 - The Necessary requirements which include four items: institutions and infrastructure, macroeconomic environment, health, and primary education. 2- Efficiency incentives (higher education, training and efficiency, goods market, labor market and financial markets, technological preparedness, and Market size. 3- Innovation and business development 
between 2009 and 2012. An average score of 3.1 in the different pillars of the KEI in 2019, is indicated in table 3. ${ }^{(18)}$

\begin{tabular}{|c|c|c|c|}
\hline year & $\begin{array}{c}\text { KEI } \\
\text { score }\end{array}$ & $\begin{array}{c}\text { Rank } \\
\text { KEI }\end{array}$ & $\begin{array}{c}\text { Number of } \\
\text { countries }\end{array}$ \\
\hline 1995 & 4.56 & 87 & 144 \\
\hline 2000 & 4.31 & 89 & 145 \\
\hline 2008 & 4.03 & 79 & 145 \\
\hline 2009 & 4.08 & 90 & 145 \\
\hline 2012 & 3.78 & 96 & 144 \\
\hline
\end{tabular}

Source: Egypt's Medium -Term Plan 2018/19-2021/22

Table3 Egypt's score 2018 EBRD Knowledge Economy Index ${ }^{(19)}$

\begin{tabular}{|c|c|l|c|c|c|c|}
\hline $\begin{array}{c}\text { Egypt } \\
\begin{array}{c}\text { Score in } \\
\text { EBRD } \\
\text { Knowledge } \\
\text { economy } \\
\text { index }\end{array}\end{array}$ & $\begin{array}{c}\text { Egypt } \\
\text { Rank } \\
\text { among } \\
\text { EBRD } \\
\text { economies }\end{array}$ & Pillar & $\begin{array}{c}\text { Institutions } \\
\text { for } \\
\text { Innovation }\end{array}$ & $\begin{array}{c}\text { ICT } \\
\text { Infrastructure }\end{array}$ & $\begin{array}{c}\text { Skills for } \\
\text { Innovation }\end{array}$ & $\begin{array}{c}\text { Innovation } \\
\text { System }\end{array}$ \\
\hline 3.11 & $\begin{array}{c}36 \text { out of } \\
37\end{array}$ & Score & 3.54 & 3.42 & 3.03 & 2.46 \\
\hline
\end{tabular}

Source: European Bank for Reconstruction and Development: Knowledge Economy Index,2019

https://www.ebrd.com/news/publications/brochures/ebrd-knowledgeeconomy-index.html

A recent published index" the Digital Evolution Index" (DEI) segments the countries into four categories: stand outs, stall outs, break outs and watch outs. Egypt is one of 43 countries classified as "watch outs", which means it has a current low state of digitalization "Watch outs" countries have a number of common characteristics, massive infrastructural gaps,

(18) The lowest score is zero and the highest is 10

(19) The institutions for innovation refer to economic openness, business environment and governance. The skills for innovation include general skills and specialized skills. Regarding the innovation system it is composed of inputs, outputs, and linkages. ICT infrastructures include ICT availability and ICT sophistication. 
institutional constraints, low access to the internet, low consumer demands, and shortage of mobile- internet. In 2017 Egypt ranked 54 out of the 60 countries for which the digital evolution index has been calculated (Chakravorti and Chaturvedi, 2017) and (OECD ,2017).

As for the Global Innovation Index, which is made up of seven subindices ${ }^{(20)}$, Egypt's overall rank has deteriorated from 92 out of 131 countries in 2019 to 96 out of 131 countries in 2020. It is worth noting that according to Egypt Vision 2030, it is planned to improve this ranking to reach 30 . We judge this as a highly optimistic objective given its current low rank in the innovations' input and output: 96/131. ${ }^{(21)}$

Figure 2 shows the evolution of Egypt's rank in the Ease of Doing Business index from 2012 to $2019^{(22)}$. As figure 2, shows Egypt's rank has consistently been over 100 , which is a relatively low ranking reflecting a low level of economic efficiency. In 2019 Egypt ranked 114 out of 190 countries, recording an improvement compared to the previous years, which is an indicator of efforts to improve laws and regulations and to make the business environment more conducive to foreign and domestic investment. Nevertheless, still a long way must be taken in order to move forward in the ranking.

\footnotetext{
${ }^{(20)}$ Institutions, Human Capital and Research, Infrastructure, Market Sophistication, Business Sophistication Knowledge and Technology output and Creativity output (GII,2020).

${ }^{(21)}$ Ease of Doing Business index is published by the world bank. Doing Business measures aspects of business regulation affecting small domestic firms located in the largest business city of 190 economies. In addition, for 11 economies a second city is covered. Doing Business covers 12 areas of business regulation. The ease of Doing Business index covers 10 areas: starting a business, dealing with construction permits, getting electricity, registering property, getting credit, protecting minority investors, paying taxes, trading across borders, enforcing contracts, and resolving insolvency. (World Bank 2019) ${ }^{(22)}$ Ease of Doing Business index is published by the world bank. Doing Business measures aspects of business regulation affecting small domestic firms located in the largest business city of 190 economies. In addition, for
} 
Figure 2. The Evolution of Egypt's Rank in the Ease of Doing Business index

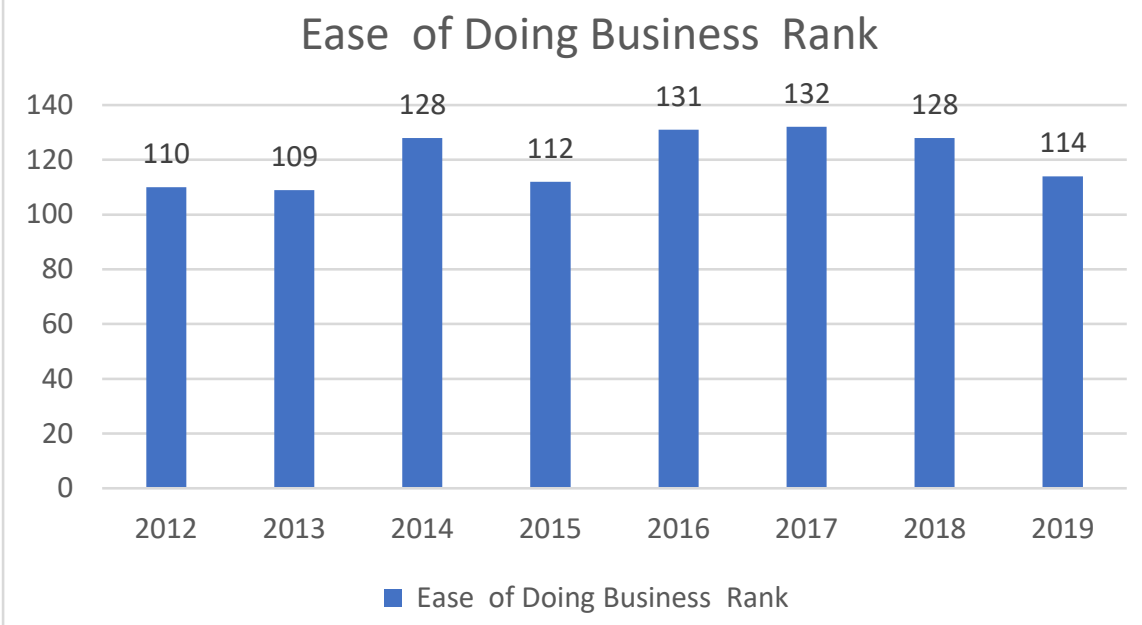

Source: Ministry of Planning and Economic Development, World Bank 2019

Finally, Egypt "s rank in the Global ICT Development Index in 2017 has only improved to one position to be 103 out of 176 countries instead of 104 in 2016. (Global ICT Development Index, 2017). It was planned to improve its rank to reach 85 in 2020 and is planned to reach a rank of 60 in 2030 (Egypt Vision 2030) (23)

The ICT development process towards becoming an information society, is measured using the three-stage model that reflects the readiness and intensity and the impact of the effective use of ICT (Global ICT Development Index, 2017). ${ }^{(24)}$

The ICT sub- index in the Global Innovation Index (GII) indicates that Egypt ranked 73 in 2020. According to Egypt's Sustainable Development Strategy (Egypt Vision 2030) it is planned to improve its ranking to reach 30,

(23) Figures of The Global Development Index 2018,2019 have not been released. They only published the intended plan for issuing the report of 2020 .

(24) The Global Development Index did not issue its report for the years 2018,2019. It published its intended plan for issuing the report of 2020. 
which is a highly optimistic estimate versus its low rank in the innovations' input and output: 96/131. ${ }^{(25)}$

An integral part of the transformation to a knowledge-based economy is investing in the ICT sector. Public investments in the ICT sector in Egypt remains low, and the ICT sector in Egypt remains a small sector in terms of its direct contribution in GDP. Its contribution to the GDP at fixed prices in 2004 was $0.93 \%$ compared to Western Europe (2.5\%) and the USA (3.37\%) in the same year. Its contribution to the GDP at fixed prices continued to be relatively small though the various strategies and plans reflecting the importance of the ICT sector to the Egyptian economy. Investments in the sector constituted 14\%, in 2018, $16.8 \%$ in 2019 and declined to $15.2 \%$ in 2020 http://www.egyptictindicators.gov.eg/en/Pages/viewer12.html). Its share in public investment reached $2 \%$ on average during the period from 2002/03 to $2018 / 19$, and its share in total planned investments in the medium- term plan $2018 / 19-2021 / 2022$ is estimated to reach $4.5 \%$. Yet, it is considered one of the fastest growing sectors with an average annual growth rate of over $10 \%$ in the communication sector and $4 \%$ in the information sector during the period 2007 to 2019 . The value added by the communication sector has been consistently growing faster than overall economic activity. This is the case as well for the information sector, although at a much lower rate (See Figure 3).

(25) Egypt ranked in the innovation input: Institutions: 115, Human Capital and Research 90, Infrastructure 99, Market Sophistication 106, Business Sophistication 103. Concerning the innovation output, it ranked in Knowledge and Technology: 65 and in Creativity: 101. 
Figure 3. The Growth Rate in Added Value at Constant Factor Cost for Communication and Information, GDP

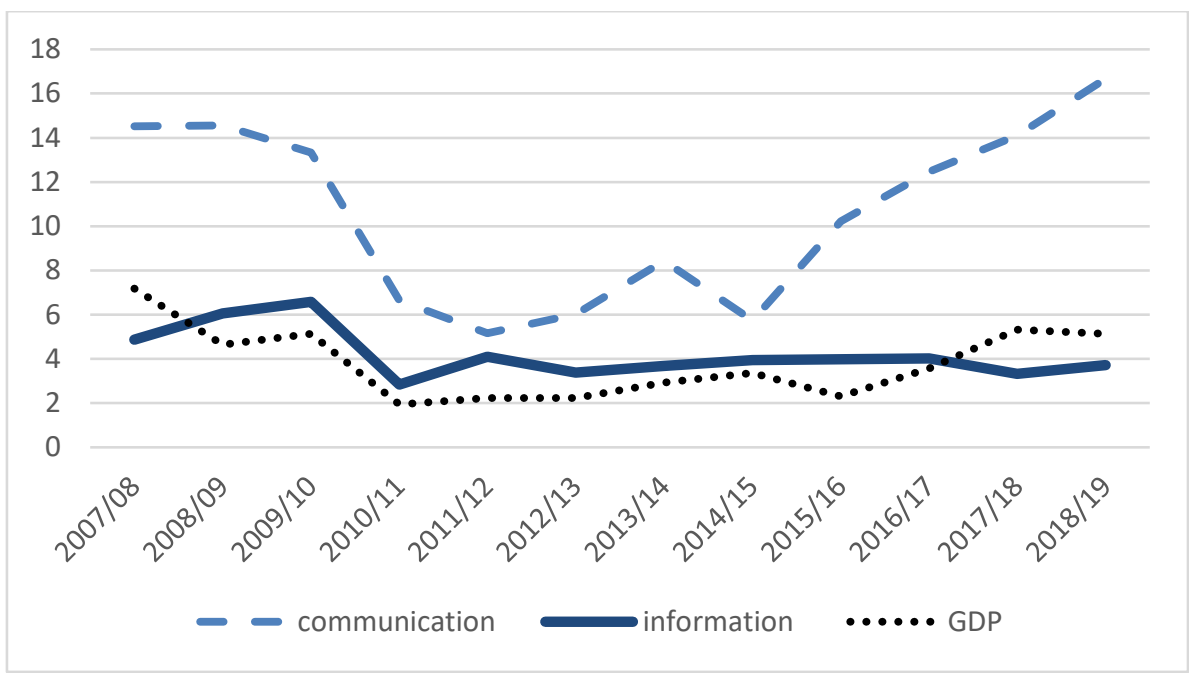

Source: Ministry of Planning and Economic Development Data

Concerning the growth rate in total public investment and in public investment in ICT (in fixed prices), Figure 4. shows that public investment in ICT increased in the last three years that in recent years. From 2016/2017 up to date the growth rate in public investment in ICT is exceeding the growth rate in total public investment, which is consistent with the 2030 Egypt's vison for sustainable development to improve the infrastructure needed to support the digital transformation.

Concerning investment in human capital, the Ministry of Communication, and Information Technology (MCIT) has an initiative called "Our Future is Digital" which aims to train 100,000 young Egyptians and develop their ICT skills in areas of high market demand, including website design, data analysis, and digital marketing. Also, the National Academy of Information Technology for Persons with Disabilities (NAID established in 2018, aims to stimulate assistive technologies to enable persons with disabilities to develop their ICT skills. (Digital Egypt, Ministry of communications and information technology, https://mcit.gov.eg/en/Digital_Egypt .) 
Figure 4: Growth Rates of Public Investment and Public Investment in ICT (in fixed prices)

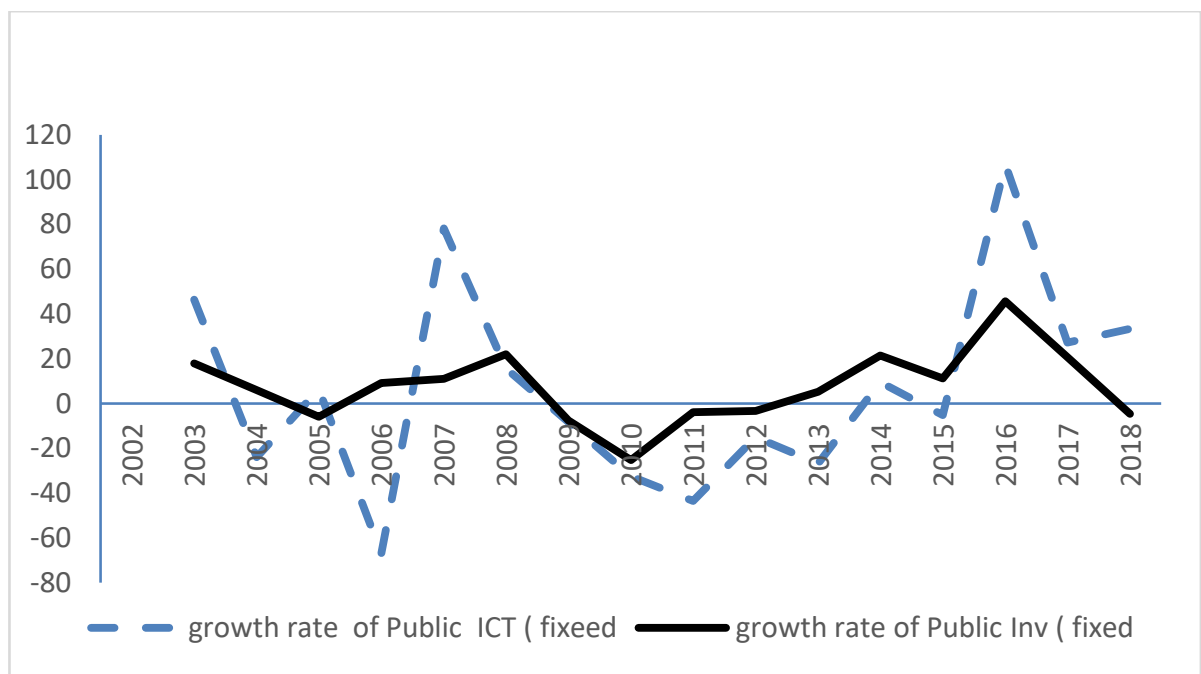

Source: Ministry of Planning and Economic Development Data and IFS Data

\section{Conclusion}

The research paper illustrated the economic role of the state in the different schools of thought. Two objectives appear to be at the center of the economic role of the state in the discussed theoretical framework: the first objective is to provide public services- whether alone or in collaboration with other stakeholders. The second objective is to provide space for individual freedoms to contribute to the economic growth through a knowledge - based society.

Concerning the first hypotheses assumes that assumes that the state in Egypt is struggling with its economic role, and that the 4.0 poses challenges to that role. Historically, especially in underdeveloped countries including Egypt, "statism" has overridden the existence of an "entrepreneurial state mind". State institutions did not provide the second objective for several decades, and though with a margin of freedom that allowed individuals to perform certain economic activities, these were neither sustainable, nor 
competitive. The policies in the various strategies and plans reflect an interplay between the state and technology, rather than between state, technology, and the individual. The former strategies - to transform the economy towards a knowledge- based and digital economy, resulted in a state- type institutions that has a hegemony over the economic activities, including the economization of knowledge. Drafting alone the policies that lead to digital transformation, made it difficult for the state in Egypt to accelerate the pace to engage with 4.0. This requires the various institutions to change its culture to recognize the importance of the roles of non-state actors in producing knowledge and innovation in a participatory manner. The latter demands an institutional environment that is characterized by freedom of the individual, as an integral part of modern economy and an important element for providing for 4.0 products.

Regarding the state perception of the provision of public goods, is not clear how the government of Egypt understands ICT services (the infrastructure for digitalization). If it perceives it as a public good, still public investment in ICT remains a low percent of total public Investment, and challenging. Regarding the private sector investment in ICT and digitalization, it is increasing, and proves that it is not perceived as a public good. The new investment law 2017 dedicates a full chapter to potential investments in ICT and avails opportunities, incentives, and exemptions, which need to be encouraged by the state.

Concerning the second hypotheses that assumes that formal institutions did not benefit from the 4.0 outcomes, and which did not result in transforming its role and policies and in positively influencing the economic growth in Egypt.

According to the modern economic order which is characterized by institutions that regulate "an enterprise economy", state institutions do not 
play a sufficient role in directing private sector and individuals to perform efficiently in producing knowledge and impact the transition towards a knowledge -based society and economic growth.

The research paper discussed the regulatory framework that enables and directs the policies of digital transformation to achieve economic growth. It is clear that the institutions in Egypt have put several strategies that constitute the legal framework for the transition towards 4.0. Most of it are state- led plans, scattered, and need to be coordinated. Otherwise, it could undermine the quality and effectiveness of the regulatory framework. Also, pre and post 2011 state policies oscillate between focusing on ICT and digital transformation policies as an aim in itself and focusing on it as a mean for economic growth. In addition, most of the government strategies and plans concerning ICT and digital transformation are risk-free. It did not include policies and indicators for unintended adverse effects due to the 4.0 innovations and products, and means to mitigate the risks of income distribution, labor market, capacity building for the poor sectors, cyber security, and trust.

Finally, digital transformation does not occur in isolation. Macroeconomic stability, well-functioning capital markets, labor markets, goods' markets and open trade policies can enable the environment for the digital economy to grow. (Chakravarty and Chaturvedi, 2017).

Benefiting from the opportunities of the 4.0 through digital transformation and improving ICT infrastructure, require settling the "rolestruggle" of the state in Egypt vis a vis the economy. This could result in a negative state role. The state vision needs to be clear in that sphere.

Accordingly, recommendations for future research could focus more on measuring the economic role of the state in improving the policy framework to achieve digital transformation and to provide for 4.0 products. It could 
further examine state-society relations of supply and demand conditions, and consumer capacity to engage in the transformation process. Future studies may also examine types of institutional culture that could accommodate with the knowledge-based economy. In addition to conducting studies that analyze the role of the private sector in improving the ICT investment sector.

\section{Regarding the policy recommendations, it should include the following:}

1. Institutions' policies should perceive the knowledge -based economy as an important as well as a complex process Thus, Government could intervene in three important areas: developing the ICT infrastructure; coordinating and strengthening the legal and regulatory framework for digital businesses; create enabling conditions to establish new markets to manage changes in the digital ecosystem.

2. Encouraging a business culture that rewards individual and company's entrepreneurship. To achieve this goal, current policies have to work on addressing the challenges of weak institutions, skills, and innovation components.

3. Reviewing the regulations to create a knowledge -based economy sectors in the various state institutions.

4. Studying the institutional digital field to identify actors who support research and development to enhance innovations.

5. Amending the e-signature law and consumer protection law to accommodate new developments in the electronic transactions sector and include articles related to online dispute resolutions.

6. Identifying required investments in the ICT and digital transformation sectors in The Egyptian Sustainable Development Strategy 2030, and allocate it among companies, individuals, and civil society to accelerate economic growth.

7. Expanding capacity building for youth on digital transformation programs and allocating more financial resources for this goal. 


\section{List of References}

1- Alissa, Sufyan, The Political Economy of Reform in Egypt: Understanding the Role of Institutions, Carnegie Papers, No.5, October 2007

2- Aubrey, Henry G., The Role of the State in Economic Development, The American Economic Review. Vol.41, No.2, 1951, p.267 pp.269-270

3- Caporaso, James A., The State 's Role in the Third World Economic Growth, The Annals of the American Academy of Political and Social Science, Vol.459, January,1982, p.105

4- Centino, Miguel A. and Joseph N. Cohen, The Arc of Neoliberalism, Annual Review of Sociology, 2012, p.318. pp.321.328

5- Central Bank of Egypt, Highlights of the Central Bank of Egypt's Fin Tech and Innovation Strategy:1-20 December, 2019, https://fintech.cbe.org.eg/Home/fund?en

6- Chaichian, Mohammed A., The Effects of World Capitalist Economy on Urbanization in Egypt, 1800-1970, International Journal of Middle East Studies 20., 1988, p.25

7- Chakravorti Bhaskar and Ravi Shankar Chaturvedi, Digital Planet 2017, How Competitiveness and Trust in Digital Economies Vary Across The World, The Fletcher School, Tufts University, 2017

8- Cuno, Kenneth M., The Origins of Private Ownership of Land in Egypt: A Reprisal, International Journal of Middle East Studies. 12, 1980, pp. 245,246

9- Dillard, Dudley, The Keynzanian Revolution and Economic Development, the Journal of Economic History, Vol. 8, No. 2.Nov. Cambridge University Press, 1948, pp. 171-177,

10- Eckstein, Alexander, Individualism and the Role in the Economic Growth, Economic Development and Cultural Change, Vol.6, No.2, 1958, p.81,p. 85

11- Egyptian Supreme Cybersecurity Council (ESCC), National Cybersecurity $\quad$ Strategy 2017-2021, 2017 https://www.mcit.gov.eg/Upcont/Documents/Publications_1212201800 0_EN_National_Cybersecurity_Strategy_2017_2021.pdf

12- Egypt Vision 2030 https://www.arabdevelopmentportal.com/sites/default/files/publication/ sds_egypt_vision_2030.pdf ) 
13- Egypt ICT Strategy, Minister of Communications, and Information Technology, https://mcit.gov.eg/en/ICT_Strategy

14- El Nawawy, Mohamed Fouad et.al., ICT Impact on Economic Growth: The Cases of Egypt and India, International Association for Management of Technology, Conference Proceedings, 2017, pp.6,7

15- Embassy of Egypt, Washington D.C. Egypt's New Investment Law: Opening Egypt for Business, http://amchamegypt.org/Egypt_Investment_FactSheet_081117.pdf

16- European Bank for Reconstruction and Development:Knowledge Economy Index,2019 https://www.ebrd.com/news/publications/brochures/ebrd-knowledgeeconomy-index.html

17- Ferguson, Adam, An Essay on the History of Civil Society (originally published in 1814), 1995, pp.10-14

18- Friedman, Milton, Capitalism and Freedom, [1961], Indianapolis Liberty Fund.2013. pp.6.10,

p.12http://files.libertyfund.org/files/2492/Friedman_CapitalismFreedom 1961.pdf

19- Gao. Xiang. State-Society Relations in China's State Led Digitalization: Progress and Prospects. The China Review, Vol. 20, No.3, August 2020, pp.3-4

20- Gärtner, Manfred, Macroeconomics, Pearson, 2016, p.29

21- Global Competitiveness Report,2020, pp.37. https://www.weforum.org/reports/the-global-competitiveness-report2020

22- Global ICT Development Index, 2017, https://www.itu.int/net4/ITUD/idi/2017/index.html.

23- Goulborne, Harry, Politics and State in the Third World, The Macmillan Press Ltd. London and Basingstake,1979, p.12

24- O'Halloran, Derek and Al, Services and Digital Economy, The World Economic Forum, 2015, https://www.weforum.org/events/globaltechnology-governance-summit-2021/sessions/tackling-digital-deserts

25- Handoussa, Heba, The Role of the State: The Case of Egypt, Working Paper 9404, Economic Research Forum, 1994, p.2

26- Hayek, Friedrich, A., Individualism and Economic Order, University of Chicago Press, 1948 , p.4, p. 8, p.11 
27- Hayek, Friedrich A., "The Use of Knowledge In Society" American Economic Review, XXXV, No. 4; September, 1945, p.12.p. 519, p.530.

28- Hayek, Friedrich A., The Road to Serfdom, Institute of Economic Affairs, London,2001, pp.40.45

29- Helm. Dieter, The Assessment: Economic Boundaries of the State, Oxford Review of Economic Policy, Vol.2. No.2, 1986, p.2. p.3. p. 6 .p.14

30- Hira. Anil, Hira. Ron, The New Institutionalism: Contradictory Notions of Change. The American Journal of Economics and Sociology, Vol.59, No.2, April 2000, pp. 268-269. p.273. p.277

31- Holcombe. Randall G., The Economic Foundations of Government, New York, New York University Press, 1994, p.32

32- Holcombe, Randall G., The Theory of Public Goods, Review of Austrian Economics, Vol. 10, No.1, 1997, p. 3, pp.7-12

33- Issawi, Charles, Egypt Since 1800; A Study in Lop-sided Development. The Journal of Economic History, Vol.XXI, No.1, March, 1961, pp.3-6

34- Johansen. Leif. The Theory of Public Goods: Misplaced Emphasis. Journal of Public Economics, No. 7. 1977. pp.147.148

35- Joya, A. The Roots of Revolt: A Political Economy of Egypt from Nasser to Mubarak, Cambridge: Cambridge University Press. 2020, pp39.41.43.55.63

36- Kamel, Sherif, .Innovation and knowledge Management in Twin Track Economies: Challenges \& Solutions: The Evolution of the ICT Sector in Egypt Partnership4Development, The American University in Egypt, 2007 ,pp.845-847

37- Karakoc, Ulas et.al., Industrialization in Egypt and Turkey 1870-2020, in Hjortshoj, Kevin, The Spread of Modern Industry to the Periphery since 1871, Oxford university Press, 2017, pp.4-5

38- Keynes, Meynard J., The End of Laissez- Faire and the Economic Consequences of the Peace, New York, Prometheus Books, 2004, p. 16

39- Knowledge Economy Index, the European Bank for Research and Development, 2019, p.14

40- Klein, Philip. "Has Institutionalism Won: The Developmental Debate?", Journal of Economic Issues 11, No.4, 1977, p. 787 
41- Knight, Frank H., The Role of the Individual in the Economic World of The Future, Journal of Political Economy, Vol.59, No.6. Dec. 1941.p.818 p.820, p.826

42- Krader, Lawrence, Formation of the State, Prentice Hall Inc., Englewood Cliff, 1968, p.46

43- Maki,Uskali, Gustafsson Bo. and Knudsen. Christian (eds.), Rationality, Institutions and Economic Methodology, London, Routledge, 1993, p.39

44- Mill. John Stewart, On liberty. The Walter Scott Publishing Co.Ltd. 2011. pp.23-24

45- Miller. Eugene F., Von Hayek's the Constitution of Liberty: An Account of Its Argument, Economic Affairs, London.2001, p.42

46- Ministry of Planning and Economic Development, Egypt Vision 2030. 2016 https://www.mped.gov.eg/EgyptVision?lang=en

47- Ministry of Planning and Economic Development, Medium Term Plan for Sustainable development (2018/19-2021/22)

48- Ministry of Planning and Economic Development, Monitoring and Administrative Reform, Egypt Vision 2030, 2016.

49- Ministry of Communications and Information Technology, Digital Egypt, https://mcit.gov.eg/en/Digital_Egypt

50- Mohamed, Ahmed Ezzeldin, The Welfare State in Egypt, 1995-2005: A Comparative Approach, Columbia University, 2014

51- Mountjoy, Alan, The Development of Industry in Egypt, Economic Geography, Vol.28., No.3, 1952, p.10

52- Najarajan, K.V., Egypt's Political Economy and the Downfall of the Mubarak Regime, International Journal of Humanities and Social Science, Vol.3, No. 10, May 2013

53- North, Douglas C., Institutions, Institutional Change and Economic Performance, New York, Cambridge University Press, 1990, p.18

54- Official Newspaper, No.22, June,2021, pp.5-15, College for Smart and Secured Versions.

55- O'Halloran, Derek and Kvochko Elena, Industrial Internet of Things: Unleashing the Potential of Connected Products and Services, The World Economic Forum, 2015,p.4

56- OECD Digital Economy Outlook 2017,OECD Publishing, .2017 http://dx.doi.org/10.1787/9789264276284-en 
57- Pardee, Frederick, Sustainable Development Goals Report: Egypt 2030, November, Center for International Future and UNDP,2018

58- Philbeck, Thomas and Davis, Nicholas, The Fourth Industrial Revolution: Shaping A New Era, Journal of International Affairs, Vol.72, No.1, 2019, p.17.p.21

59- Rahman, Sabeel, Conceptualizing the Economic Role of The State: Laissez-Faire, Technocracy and the Democratic Alternative, Polity, Vol.43, No.2, April, 2011, p.265 pp. 276-278

60- Reisman, David A., Adam Smith on Market and State, Journal of Institutional and Theoretical Economics, June 1998, Vol. 154, No.2, p.358

61- Rutherford, Malcolm, The Old and New Institutionalism: Can Bridges Be Built? Journal of Economic Issues, Vol.29, No.2, June,1995, p.443

62- Samuelson, Paul A., The Pure Theory of Public Expenditure, Review of Economics and Statistics, 26, November, 1954, pp.387-388, p.391

63- Sandmo, Angar, Public Goods and the Technology of Consumption, Review of Economic Studies, October, 1973, p.518

64- Klaus Schwab, "The Fourth Industrial Revolution “, the World Economic Forum, 2016.

65- Schwab, Klaus, The Global Competitiveness Report 2019, World Economic Forum, 2019

66- Shuo-Yan Chou, The Fourth Industrial Revolution: Digital Fusion with Internet of Things, Journal of International Affairs, Vol.22, No.1. Fall 2018-Winter, 2019, p. 108

67- Solow, Robert, A Contribution to the Theory of Economic Growth, Quarterly Journal of Economics, 1956, pp. 65.94

68- Stiglitz. Joseph E., Another Century of Economic Science ,1991, p.138

69- Teck-Boon Tan and Wu Shang -Su, Coping with an Uncertain Future, Public Policy Implications of the Fourth Industrial Revolution for Singapore, Rajaratnam School of International Studies, 2017, p.19

70- United Nations Conference on Trade and Development (UNCTAD), ICT Policy Review: National E-Commerce Strategy for Egypt, 2017

71- Veblen. Thorstein, The Theory of Business Enterprise, Augustus M. Kelly, Clifton NY., 1964, p.448

72- Weingast, Barry R., The Economic Role of Political Institutions: Market Preserving Federalism and Economic Development, Journal of law, 
Economic and Organization, Vol.11, No.1, April 1995, p. 2 p.4 p. 6,p.10,p.15

73- William, Raymond, Sadat's Open Door: Opposition from Within, Social Problems, Vol.28, No.4, 1981, pp.380,381

74- World Bank Group, Doing Business, 2020

75- World Bank Report, The State in a Changing World, 1997, p.1. pp. 1214.pp.36-38.p.40.p.64

76- World Bank, Poverty and Shared Prosperity, Country Inequality Report ,2016, p. 28, and see also: The $4^{\text {th }}$ Industrial Revolution, The Guardian, $16 / 7 / 2017$

77- World Economic Forum, Digital Economy and New Value Creation, 2017, p.4

78- World Economic Forum, Global Risk Report, $15^{\text {th }}$ Edition, Marsh and McLennan and Zurich Insurance Group, 2020, p.7

79- http://www.egyptictindicators.gov.eg/en/Pages/viewer12.html).

80- (https://itida.gov.eg/English/Pages/Silicon-Waha.aspx).

81- (http://www.digitalopportunity.itida.gov.eg/Arab\%E2\%80\%A6/Pa ges/AboutUs.aspx).

82- Cornell, SC Johnson, College of Business INSEAD, World Intellectual Property Organization, Global Innovation Index 2020, "Who will Finance Innovation'.

$$
\begin{aligned}
& \text { 83- العروي, عبد الله, مفهوم الدولة, المركز الثقافي العربي, الدرار البيضاء, الدغرب, ,I91 ص ع ا }
\end{aligned}
$$

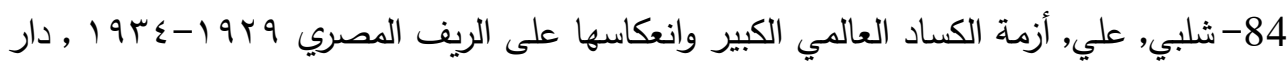

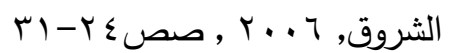

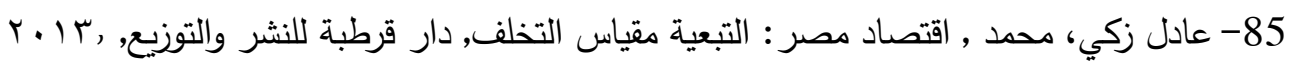

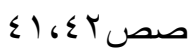

